\title{
Can Overconfident Executives Restrain Overinvestment?
}

\author{
Xuanbing Liu \\ Business Administration College, South China University of Technology, Guangzhou, China \\ Email: 549166275@qq.com
}

How to cite this paper: Liu, X.B. (2017) Can Overconfident Executives Restrain Overinvestment? Modern Economy, 8, 10561068.

https://doi.org/10.4236/me.2017.88073

Received: July 26, 2017

Accepted: August 19, 2017

Published: August 22, 2017

Copyright (C) 2017 by author and Scientific Research Publishing Inc. This work is licensed under the Creative Commons Attribution International License (CC BY 4.0).

http://creativecommons.org/licenses/by/4.0/

\begin{abstract}
This paper uses the data of the public company from 2013 to 2015 to explore the relationship between executives' overconfidence and overinvestment when the company's financing ability is different. Unlike previous studies, the result of this study shows that overconfidence may curb overinvestment when the company's financing capacity is poor. It is when the financing capacity is strong that overconfidence will exacerbate overinvestment. A lot of studies show that overconfident executives increase overinvestment because of underestimation of risk, and our study gives a different view.
\end{abstract}

\section{Keywords}

Financing Ability, Overconfidence, Overinvestment

\section{Introduction}

In the perfect capital market, the enterprise's investment and financing activities are independent. However, a large number of papers prove that the agency problem will induce executives to do over-investment for their self-interest [1]. The interpretation of over-investment behavior by agent theory is based on the assumption that executives are completely rational. In real life, executives are often irrational, and they may generate cognitive errors due to over-confidence [2] [3], making the investment level out of the optimal range. So far, academics believe that over-confident executives will overestimate the benefits and underestimate the risk, which will lead to excessive investment. However, no scholars have discussed whether the over-confidence will inhibit excessive investment. This paper examines the relationship between overconfident executives and overinvestment in the context of different corporate financing capacity, and whether executives' overconfidence can curb over investment.

The contribution of this paper is mainly reflected in the following two points: 
First, this paper explores the possibility of overconfidence inhibit excessive investment, rather than admit the negative effects of deterioration of excessive investment. Second, this paper researches the company's potential financing capacity rather than the impact of current liabilities on investment decision-making.

The Structure of this paper is as follows: the second part is the literature review and hypothesis. The third part is the research design. The fourth part is the empirical result. The fifth part is the robustness test. The last part is the conclusion of this paper.

\section{Literature Review and Hypothesis}

\subsection{Literature Review}

The conflict of interest between the commissioner and the agent is an important reason for the over-investment of the executive, which was first proposed by Jensen In his opinion, the separation of control and ownership would breed agency problems and create a conflict between shareholders and executives. For example, executives may abuse resources for mergers and acquisitions, and these mergers and acquisitions tend to cause losses for the company, rather than creating wealth [1]. A large number of scholars confirmed this view from a number of angles afterwards [2] [3].

In 2002, Heaton J [4] pointed out that even if there is no agency problem, overconfident $\mathrm{CEO}$ can also lead to excessive investment through the establishment of theoretical models. Because overconfident CEO overestimate the company's internal project income, so there is excessive investment tendencies [5] [6]. In the case of M \& A investment, Malmendier U et al. [7] and Doukas J.A. [8] found that the over-confident CEOs have a higher probability than that of non-over-confident CEOs in the $\mathrm{M} \& \mathrm{~A}$ investment, and paid higher prices, obtain Lower yields, which will finally damage the corporate benefits [9] [10] [11]. Kolasinski A C [12] argues that mergers and acquisitions will improve when the overconfident executives have experienced personal failures in stock investment, which also implies the negative impact of overconfidence on $M \& A$ performance. In addition to capital investment and mergers and acquisitions, overconfident executives have higher R \& D investment levels [3] [9], but it is possible to reduce long-term stock returns and financial performance, indicating that there are also over-investment issues in research and development [13]. But it is not hard to notice that overconfident CEO does not equate with the high level of investment. Sometimes, overconfident executives can even lead to underinvestment. When overconfident CEOs overestimate the company's overall outlook, it will underestimate the cost of financing, resulting in underinvestment [14] [15]. In a word, there are two tendencies for the overconfident CEO, one is overestimated project revenue, which easily lead to over-investment. The other is the overestimation of the company's overall income, which easily lead to inadequate investment.

So, the question is when will the excessive investment tend to prevail or when 
will the lack of investment tend to prevail? Some scholars believe that overconfident CEO's inefficient investment type depends on free cash flow. When companies have free cash flow, overconfident executives will abuse free cash flow and exacerbate overinvestment. when the company's cash flow is not sufficient to meet the efficiency of investment, the overconfident executive will be underinvested because of the resistance to external financing [11] [14] [15] [16] [17]. According to this viewpoint, overconfident executives always reducing their investment efficiency.

However, in recent years, studies have shown that there are other factors that affect the overconfident management of investment income and financing costs of the trade-offs. Therefore, overconfident executives may not always reduce investment efficiency. At present, some scholars have suggested that overconfident executives may underestimate the lack of investment due to underestimation of risk. So, is there a possibility that overconfident executives are likely to inhibit excessive investment due to disgusting of external financing?

Malmendier and Tate [18] emphasizes that overconfident CEOs do not necessarily worsen over-investment issues, and he must weigh the benefits and costs at the same time. Overconfident CEOs believe that internal financing costs and risk-free credit rates are accurate, and external financing costs are high. Therefore, there is little difference in the opinion of overconfident executives and peers on the external financing when the enterprise credit rating is good. However, the overconfident CEO will show the preference for internal financing when the enterprise has a low credit.

\subsection{Hypothesis}

When the overconfident executives have a strong preference for internal financing, the company will have a "financing constraints" problems. Specifically, overconfident executives believe that the company's prospects are better, the market underestimated its operating conditions, so they cannot correctly understand the company's financing costs. They tend to use internal funds because the external financing costs are higher. This can explain several behaviors of the overconfident executives, such as borrower's conservative [19], lack of investment, low dividend and so on. But it should be noted that financing constraints may not be a bad thing. Financing constraints can reduce agency costs for excess cash. In excess of corporate finance constraints, excess cash leads to overinvestment. However, the relationship between excess cash and overinvestment is not obvious when firm financing is strong [20]. Coincidentally, Mi Meg Luo [21] also believes that financing constraints will reduce the availability of foreign financing, so that executives prefer internal financing, which will curb excessive investment. When the company faced with financing constraints, it will have more profitable future investment and higher stock returns. Because the executives' overconfidence is equal to internal "financing constraints", we can expect that when the company's financing capacity is weak, the overconfidence of execu- 
tives may play a similar role in financing constraints and inhibit over-investment. Overconfident executives will tend to maintain a high level of cash holdings and prepare for future investment opportunities. In this case, hypothesis 1 is proposed.

H1: When the company's financing capacity is weak, compared with nonconfident executives, overconfident executives have a weaker tendency in overinvestment.

When corporate finance is strong, overconfident executives do not have the financing concerns, so their overestimation of project gains and underestimation of risk will be very prominent and more likely to promote overinvestment. Thus, hypothesis 2 is shown as follow:

$\mathrm{H} 2$ : When the company's financing capacity is strong, compared with nonconfident executives, overconfident executives have a stronger tendency in overinvestment.

\section{Research Design}

\subsection{Data Sources and Software}

This article use the data of both Shenzhen and Shanghai public companies from 2013 to 2015 as the primary sample. These data was from the wind and CSMAR database. CSMAR is one of the most authoritative financial databases of Chia stock market. In this paper, the samples will be further screened according to the following conditions:

1) Financial industry companies is abandoned since there is a big difference in the financial characteristics between financial listed companies and other industry.

2) Removing the new listing enterprises because of unstable financial indicators and difficulties in follow-up data processing.

3) ST and $\mathrm{ST}^{*}$ enterprises are also removed. In order to avoid delisting, those companies will substantially adjust the level of investment in order to meet the capital market preferences, which will lead to deviation of the relevant value from the normal value.

4) Remove the listing enterprises which lack important information for the later regression analysis.

At last, we have 1319 observations for regression analysis.

As for the software, we adopt stata 13.0 for regression analysis.

\subsection{Measuring Overinvestment}

There are primarily two ways of measuring overinvestment, namely inefficient method. One is the indirect method, which is also known as investment-cash flow sensitivity method, and the other is the direct method, which is also known as the financial forecast method.

Investment-cash flow sensitivity method was first used to measure the level of underinvestment caused by the lack of financing constraints. However, agency 
problems and overconfidence can also account for investment-cash flow sensitivity, therefore overinvestment and underinvestment can both be expressed as investment-cash flow sensitivity [13]. Investment cash flow sensitivity method depends entirely on the prior classification of the enterprise in determining the lack of investment and excessive investment, which indicate a great limitation of this method.

In contrast, Richardson's [6] financial forecast is more straightforward. First of all, the positive and negative residues in this model can be used to determine the direction of inefficient investment. Secondly, the size of the residual items also can be used to directly measure the extent of inefficient investment.

It is determined that Richardson's method is more suitable for this study by comparing these two method. Therefore, we will use the financial forecast method to measure the degree of overinvestment. The formula is as follows:

$$
\begin{aligned}
\Delta \operatorname{Inv}_{i, t}= & \beta_{0}+\beta_{1} \text { Growth }_{i, t-1}+\beta_{2} \text { Cash }_{i, t-1}+\beta_{3} \operatorname{Lev}_{i, t-1}+\beta_{4} \operatorname{Size}_{i, t-1}+\beta_{5} \text { Age }_{i, t-1} \\
& +\beta_{6} \operatorname{Ret}_{i, t-1}+\beta_{7} \Delta \operatorname{Inv}_{i, t-1}+\text { Years }+ \text { Industries }+e_{i}
\end{aligned}
$$

$\Delta \operatorname{Inv}_{i, t}$ stands for the new investment levels, $\Delta \operatorname{Inv}_{i, t}^{*}$ means the best investment level of the company in the ideal state.

The investment is effective at this time. The optimal level of investment is determined by a number of factors, namely the company's growth opportunities, cash holdings, and financial leverage. In addition, the formula also incorporates the year and the industry dummy variable as a control variable. Formula (1) the residuals of the regression results ei, which is the current level of company's inefficient investment.

If $e_{i}>0$, indicating that the company has experienced over-investment.

The variable definition of formula (1) is shown in Table 1, relevant data is from the wind database.

In order to eliminate the effect of extreme values on the regression results, all variables in this regression was performed with $1 \%$ shrinkage. New regression result of investment was shown in Table 2.

As can be seen from Table 2, all explanatory variable coefficients are tested by significance, $\mathrm{R}^{2}$ is about 0.3 , and the overall regression is reliable. The method of

\begin{tabular}{|c|c|}
\hline parameter & Calculating method \\
\hline$\Delta \operatorname{Inv}_{i, t}$ & $\begin{array}{l}\text { Constructing the fixed assets, intangible assets and other long-term assets in paying } \\
\text { the cash/total assets at the beginning of the year }\end{array}$ \\
\hline Growth $_{i, t-1}$ & $\mathrm{~PB}$ at the beginning of the year \\
\hline Cash $_{i, t-1}$ & (cash + short-term investment) in this year/total assets at the beginning of the year \\
\hline $\operatorname{Lev}_{i, t-1}$ & Asset - liability ratio at the beginning of the year \\
\hline Size $_{i, t-1}$ & LOG (total assets at the beginning of the year) \\
\hline Age $_{i, t-1}$ & The age of the enterprise at the beginning of the year \\
\hline Ret $_{i, t-1}$ & ROE in last year \\
\hline
\end{tabular}

Table 1. The definition of parameter of Formula 1. 
Table 2. The regression of overinvestment.

\begin{tabular}{ccccccc}
\hline$\Delta \mathrm{Inv}_{t-1}$ & Growth & Cash & Lev & Size & Age & Ret \\
\hline $0.45^{* * *}$ & $0.00046^{* * *}$ & $-0.011^{* * *}$ & $-0.0088^{* *}$ & $-0.0058^{* * *}$ & $-0.0003^{* *}$ & $0.0380^{* * *}$ \\
-0.0088 & -0.00015 & -0.0029 & -0.0036 & -0.0014 & -0.00013 & -0.0057 \\
$\mathrm{~N}$ & 7497 & & & & & \\
$\mathrm{R}^{2}$ & 0.334 & & & & & \\
${ }^{* * *} \mathrm{p}<0.01,{ }^{* *} \mathrm{p}<0.05,{ }^{*} \mathrm{p}<0.1$. & & & & &
\end{tabular}

Richard [6] can be used to calculate the degree of overinvestment.

\subsection{Overconfidence Measuring}

In measuring the overconfidence of executives, two problems need to be solved. First, determine the specific positions of executives. Second, choose a method of measuring excessive self-confidence.

In terms of executives, the $\mathrm{CEO}$ is the major studying object for most foreign scholars. But the position of CEO does not exist in most of our company, the position that similar with $\mathrm{CEO}$ is general executive. The decision-making power of the general executive is weak and the relevant data is insufficient, so our scholars sometimes use the executive team or the whole company as the research object. But we believe that over-confidence is a personal psychological characteristics, therefore we should try to avoid the team as a decision-making subject. Considering that chairman of the board is an important decision-makers and the data is relatively sufficient, so the executives will be set as chairman of the board in this article.

In judging whether executives are overconfident, profit forecasting method [11] and holding law [16] is the most widely used method in China. Considering the strict rules of China's regulatory authorities on profit forecasting, the holding method is more ideal. After removing the companies whose chairman was changed, we classified the chairman according to its holding behavior. When the chairman of the board only increased the number of shares for three consecutive years, and the reasons for the stock growth is not dividends, it will be classified as OC (overconfidence), assigned to 1 . If the chairman had the same number of shares or sold the stock in 2013-2015, then he will be classified as non-overconfidence executives, 0 is assigned to OC. If there is a lack of shares held by the chairman of the board, then its classification will be suspended. The data of the shares holding by the Chairman is from the CSMAR database.

\subsection{Financing Capacity Measuring}

In the evaluation of corporate financing capacity, the bond rating is a common indicator of foreign scholars [22] [23]. However, China's bond rating mechanism is not perfect. In this article, the $\mathrm{Z}$ value will be used to determine the company's financing capacity. There are two $Z$ models that can be used at present: Altman (1968) [24] draws on the five variable $Z$ model proposed by rating team 
of Moody's and S \& P, and the Chinese Z model proposed by Zhang Ling (2004) [25]. Chinese $Z$ value model of Zhang Ling (2004) [25]. is based on the situation of the listed companies before 2004. However, china has experienced a repaid development of capital market, the situation of the listed companies nowadays is quite different from that time. On the contrary, the foreign capital market has been relatively developed, Altman $\mathrm{Z}$ value model is still used by the majority of analysts today, $Z$ value is also constantly updated in the database. After comparison, we decided to use the international common Altman $Z$ value to measure the sample company's financing capacity. The companies in the sample was ranked according to $Z$ value. The higher the $Z$ value, the higher the ranking, the stronger the financing capacity. On the contrary, the lower the $Z$ value, the lower the ranking, the weaker the financing capacity.

Dummy variables were sets up to measure financing capacity in this paper. The specific method is to rank the company according to the $\mathrm{Z}$ value and make three equal point.

Since this paper focus on the influence of the overconfident executives on overinvestment when the financing ability is weak, therefore, the dummy variable is set as "weak financed". For the company whose financing capacity ranking is located in the latter $1 / 3$, the financing capacity of the company is weak and that variable "weak financing" $=1$. For the company whose financing capacity is located in the top $1 / 3$, the financing capacity of the company is strong and that variable "weak financing" $=0$

\subsection{Model Design}

After obtaining the level of the company's excessive investment, financing capacity and the chairman's overconfidence, impact of over-confidence and financing capacity on over-confidence can be tested. This article will carry out two types of regression.

First of all, this article will conduct regression for all the samples to understand the overall situation, the specific formula can be seen in formula 3 .

After obtaining the level of the company's excessive investment, financing capacity and the chairman's overconfidence, impact of over-confidence and financing capacity on over-confidence can be tested. This article will carry out two types of regression.

First of all, this article will conduct regression for all the samples to understand the overall situation, the specific formula can be seen in formula 3 .

over investment

$=\beta_{0}+\beta_{1}$ over confidence $+\beta_{2}$ Z-lack $+\beta_{3}$ over confidence $*$ Z-lack

$+\beta_{4}$ authority $+\beta_{5}$ concentration $+\beta_{6}$ board $_{i, t-1}+\beta_{7}$ FCF

Afterwards, this paper will conduct regression respectively according to the grouping situation of $Z$. The sample is divided into three groups according to the grouping of $\mathrm{Z}$ value: strong financing ability, common financing ability and weak financing ability. The regression analysis is carried out to observe the coef- 
ficient and significance level of the three sub-samples. Specific formula can be seen in formula 4.

$$
\begin{aligned}
\text { over investment } & =\beta_{0}+\beta_{1} \text { over confidence }+\beta_{2} \text { Z-lack }+\beta_{3} \text { authority } \\
& +\beta_{4} \text { concentration }+\beta_{5} \text { board }_{i, t-1}+\beta_{6} \text { FCF }
\end{aligned}
$$

In the formulas 3 and 4, the definition of variables are shown in Table 3, and the relevant data comes from the wind database.

\section{Empirical Result}

\subsection{Descriptive Statistics}

Panel A, B, and C are cases of over-investment. After a series of data processing, a total of 2633 observations were obtained (Table 4).

\begin{tabular}{|c|c|}
\hline parameter & Calculating method \\
\hline Overconfidence & $\begin{array}{l}\text { Measured by a dummy variable. It has been illustrated in Overconfidence } \\
\text { measuring }\end{array}$ \\
\hline Z-lack & $\begin{array}{l}\text { "poor financial capacity", measured by a dummy variable. It has been } \\
\text { illustrated in Overconfidence measuring }\end{array}$ \\
\hline \multirow{4}{*}{ FCF } & Free cash flow. \\
\hline & $\mathrm{FCF}=\mathrm{OCF}-\Delta \mathrm{Inv}_{i, t}^{*}-\operatorname{dep}$ \\
\hline & OCF is the net cash flow created by operation activities. \\
\hline & Dep is depreciation and amortisation; \\
\hline authority & $\begin{array}{l}\text { Dummy variable. If the board chairman is appointed as manager as well, } \\
\text { authority }=1 \text {; otherwise, authority }=0 \text {. }\end{array}$ \\
\hline concentration & Ownership Concentration \\
\hline board & The size of the board \\
\hline
\end{tabular}

Table 3. The definition of parameters of Formula 3 and Formula 4.

Table 4. Description of overinvestment.

\begin{tabular}{ccccc}
\hline PANELA & obs & mean & min & max \\
full sample & 2633 & 0.0449 & $3.07 \mathrm{E}-06$ & 0.3275 \\
PANEL B (full sample) & & & & 0.3171 \\
Free Cash Flow Group & 317 & 0.0456 & $4.21 \mathrm{E}-06$ & 0.3275 \\
Lack of Cash Flow Group & 2316 & 0.0448 & $3.07 \mathrm{E}-06$ & $\max$ \\
PANEL C (full sample) & obs & mean & min & 0.3275 \\
Overconfident Group & 810 & 0.0461 & $3.07 \mathrm{E}-06$ & 0.3184 \\
Non-overconfident Group & 1823 & 0.0434 & $3.08 \mathrm{E}-06$ & $\max$ \\
PANEL D (Overconfident Group) & obs & mean & min & 0.3011 \\
Poor financing capacity & 241 & 0.0378 & $5.21 \mathrm{E}-06$ & 0.2967 \\
Normal financing capacity & 278 & 0.0490 & $3.07 \mathrm{E}-06$ & 0.3275 \\
Strong financing capacity & 291 & 0.0502 & $8.87 \mathrm{E}-06$ & $\max$ \\
PANEL E (Non-overconfident Group) & obs & mean & min & 0.3121 \\
Poor financing capacity & 669 & 0.0382 & $4.05 \mathrm{E}-06$ & 0.2989 \\
Normal financing capacity & 585 & 0.0461 & $3.77 \mathrm{E}-06$ & 0.3087 \\
Strong financing capacity & 569 & 0.0467 & $3.08 \mathrm{E}-06$ & \\
\hline
\end{tabular}


The result of Panel B shows that there is only about one-eighth of companies have free cash flow in companies with over-investment problems, indicating that free cash flow is not a major incentive for over-investment in our country. Thus, in the subsequent regression analysis, all companies with over-investment problems in the sample area will be included in this article, rather than only the company with free cash flow and over-investment.

As can be seen from Panel C, overconfident CEO is about $1 / 3$, and the overconfident executives have a higher average over-investment level than nonoverconfident executives, which is consistent with the mainstream academic point of view.

Next, we divided the sample into overconfident groups and non-overconfidence groups, respectively, to observe the over-investment situation when the financing capacity of enterprises is different. According to Panel D and Panel E, some conclusions can be draw as follows. First, regardless of whether the executives are overconfident, the stronger the company's financing capacity, the greater the average investment value. Second, for companies with weak financing capacity, the over-confident executives have a smaller average value of over-investment than non-overconfident executives.

Third, for companies with stronger financing capacity, the over-confident executives have a bigger average value of overinvestment than non-overconfident executives.

The data distribution is in consistent with the previous expectations as can be seen in descriptive statistics. Next, this paper will conduct a regression analysis, analyzing the influence of corporate financing capacity on the relationship between the over-confident executives and over-investment.

\subsection{Regression Result}

First, we conducted regression for all the samples by regression (Table 5).

As can be seen from Table 5 As can be seen from (1), The overconfidence coefficient is 0.0139 , which is significant at the $1 \%$ level. It preliminary verified that hypothesis 2 . This result is consistent with the fixed impression in academicy. This shows that executive's overconfidence and business over-investment is positively related. The reason is that the preference for investment is more valued for the overconfident executives compared with disgusting for foreign financing.

Compared with non-overconfident executives, they believe that they have strong ability in controlling risk and obtaining higher quality information. Therefore, they will overestimate the project benefit and reduce the investment efficiency.

The interaction term of "overconfidence" and "Z-lack" is -0.0686 , which is significant at the $5 \%$ level. As the coefficient of "overconfidence" is 0.0139 , that means when the financing ability is weak, the coefficient of "overconfidence" is -0.0586 , this verifies hypothesis 1 . This shows that the weak financing ability of 
Table 5. Regression result.

\begin{tabular}{|c|c|c|c|c|}
\hline \multirow[t]{2}{*}{ Dependent variable } & \multicolumn{4}{|c|}{$e_{i}($ overinvestment $)$} \\
\hline & $\begin{array}{l}\text { full sample } \\
\text { (1) }\end{array}$ & $\begin{array}{l}\text { Weak financing } \\
\text { capacity (2) }\end{array}$ & $\begin{array}{c}\text { Normal Financing } \\
\text { capacity (3) }\end{array}$ & $\begin{array}{l}\text { Strong Financing } \\
\text { capacity (4) }\end{array}$ \\
\hline OC & $0.0139^{* * *}$ & $-0.0823^{* *}$ & $0.0456^{*}$ & $0.0143^{* * *}$ \\
\hline $\mathrm{p}$ & 0.0033 & 0.0389 & 0.0811 & 0.0041 \\
\hline Z-lack & $-0.0033^{* * *}$ & & & \\
\hline $\mathrm{P}$ & 0.0058 & & & \\
\hline OC`Z-lack & $-0.0686^{* *}$ & & & \\
\hline $\mathrm{p}$ & 0.0387 & & & \\
\hline FCF & $0.0308^{\star * *}$ & $0.0408^{* * *}$ & $0.0254^{* * *}$ & $0.0362^{\star *}$ \\
\hline $\mathrm{p}$ & 0.0047 & 0.0093 & 0.0084 & 0.0125 \\
\hline athority & $0.0312^{\star}$ & $0.0950^{* *}$ & $0.0107^{\star *}$ & $0.00907^{\star}$ \\
\hline $\mathrm{p}$ & 0.0632 & 0.0484 & 0.0366 & 0.0634 \\
\hline concentration & $0.0354^{*}$ & $0.0556^{* *}$ & $0.0114^{* *}$ & $0.0383^{\star *}$ \\
\hline $\mathrm{p}$ & 0.0951 & 0.0345 & 0.0275 & 0.0325 \\
\hline board & $0.00974^{*}$ & 0.00404 & $0.00376^{*}$ & 0.0266 \\
\hline $\mathrm{p}$ & 0.0682 & 0.128 & 0.0953 & 0.162 \\
\hline Constant & $0.321^{\star * *}$ & $0.304^{* * *}$ & $0.283^{* * *}$ & $0.381^{* * *}$ \\
\hline $\mathrm{p}$ & 0.0041 & 0.0081 & 0.0792 & 0.0132 \\
\hline $\mathrm{N}$ & 1319 & 320 & 391 & 766 \\
\hline Adj $R^{2}$ & 0.145 & 0.134 & 0.184 & 0.128 \\
\hline
\end{tabular}

the company can effectively curb the tendency of high-level investment for overconfident executives. Most importantly, the sum of the interaction coefficient and the excess confidence coefficient is negative, which means excess confidence is negatively correlated with the overinvestment as a whole. These result shows that the more confident the executive when the company's financing ability is weak, the weaker the overinvestment effect. Unlike previous research, this result reveals the possibilities of suppressing overinvestment by the overconfident executives. The reason is that the overconfident executives will overlook the company's real financing cost when the financing ability is weak and believe the company is facing "financing difficulties" problem.

In this scenario, compared with non-overconfident executives, overconfident executives will more carefully consider the reallocation of funds, which is served as similar financing constraints effect. Therefore, overconfident executives will tend to maintain a high level of funds to save investment strength rather than investing in projects that are profitable but contribute little to the value of the company.

In order to further verify the two hypotheses, this paper also apply grouping regression for the sample. In this paper, the financing capacity of the first $1 / 3$ of 
the sample is classified as "strong financing ability group", the financing capacity ranked $1 / 3$ to $2 / 3$ of the sample is classified as "general financing ability group", the financing capacity ranked the last $1 / 3$ of the sample classification as "weak financing ability group". We also conducted regression respectively for two group's sample to observe the influence of the executive's overconfidence on overinvestment.

The packet regression results confirmed two hypotheses. In the "weak financing capacity" group, executives' overconfidence is negatively related to over-investment. This verifies hypothesis 1 .These results shows that the overconfident executives will reduce the level of overinvestment compared with non-overconfident executives when the company's financing ability is weak. In the "common financing ability group", executives' overconfident are positively related to over-investment, which is significant at $10 \%$ level. In the "strong financing ability group", executives' overconfidence coefficient is 0.0143 , which is significant at $1 \%$. As can be seen from (2), (3) and (4), the over-confident executives have a weak disgusting for external financing tendency when the company's financing ability is strong. The more the tendency to overestimate the benefit and underestimated risk, the easier in over-investment. Hypothesis 2 is verified again through data comparing.

\subsection{Robustness Test}

Taking into account the amount of investment should not only include the amount of investment payments, but also should consider the obtained funds from disposal of assets. Therefore, in the robustness test, we define the cash that is fixed for the construction of fixed assets, intangible assets and other long-term assets-the net cash recovered at the time of disposal of fixed assets, intangible assets and other long-term assets/total assets at the beginning of the year Excessive degree of investment. After obtaining excessive investment data, we examined the relationship between financing capacity, overconfidence and overinvestment in group. Regression was conducted by robustness test..

\section{Conclusions}

In this paper, we find that the influence direction of the overconfident executives on overinvestment is uncertain. When the company's financing ability is weak, the overconfident executives will maintain the investment strength and curb the tendency of overinvestment because of disgusting for the external financing. Only when the company's financing ability is strong, the tendency of increasing investment will be obvious for the overconfident executives, and thereby reducing the efficiency of the company's investment. In short, this article questioned the traditional academic argument. It is supposed the executives' overconfidence is probably will curb overinvestment and contribute to increasing investment efficiency.

The conclusion of this paper may explain why so many companies know that 
executives are overconfident and are still willing to hire them. On the one hand, they have the potential to ease the lack of investment. On the other hand, they may not strengthen the excessive investment. When the company's financing capacity is weak, overconfident executives can inhibit over-investment. This is undoubtedly a very valuable quality for the weak financing company.

\section{References}

[1] Jensen, M. (1986) Agency Costs of Free Cash Flow Corporate Finance and Takeovers. American Economic Review, 5, 323-330

[2] Weinstein, N.D. (1980) Unrealistic Optimism about Future Life Events. Journal of Personality and Social Psychology, 39, 806. https://doi.org/10.1037/0022-3514.39.5.806

[3] Simon, M. and Houghton, S.M. (2003) The Relationship between Overconfidence and the Introduction of Risky Products: Evidence from a Field Study. Academy of Management Journal, 46, 139-149. https://doi.org/10.2307/30040610

[4] Heaton, J. (2002) Managerial Optimism and Corporate Finance. Financial Management, 31, 33-45. https://doi.org/10.2307/3666221

[5] Ati, A. (2003) How Sensitiveis Investment to Cash Flow When Financing Is Frictionless? Journal of Finance, 58, 707-722.

[6] Richardson, S. (2006) Over Investment of Free Cash Flow. Review of Account Studies, 11, 1-47

[7] Malmendier, U. and Tate, G. (2008) Who Makes Acquisitions? CEO Overconfidence and the Market's Reaction. Journal of Financial and Economics, 20, 20-43. https://doi.org/10.1016/j.jfineco.2007.07.002

[8] Doukas, J.A. and Petmezas, D. (2007) Acquisitions, Overconfident Managers and Self-Attribution Bias. European Financial Management, 13, 531-577. http://onlinelibrary.wiley.com/doi/10.1111/j.1468-036X.2007.00371.x/abstract

[9] Hirshleifer, D., Low, A. and Teoh, S.H. (2012) Are Overconfident CEOs Better Innovators? The Journal of Finance, 67, 1457-1498. https://doi.org/10.1111/j.1540-6261.2012.01753.x

[10] Galasso, A. and Simcoe, T.S. (2011) CEO Overconfidence and Innovation. Management Science, 57, 1469-1484. https://doi.org/10.1287/mnsc.1110.1374

[11] Chen, S.S., Ho, K.Y. and Ho, P.H. (2014) CEO Overconfidence and Long-Term Performance Following R\&D Increases. Financial Management, 43, 245-269. https://doi.org/10.1111/fima.12035

[12] Kolasinski, A.C. and Li, X. (2013) Can Strong Boards and Trading Their Own Firm's Stock Help CEOs Make Better Decisions? Evidence from Acquisitions by Overconfident CEOs. Journal of Financial and Quantitative Analysis, 48, 11731206. https://doi.org/10.1017/S0022109013000392

[13] Malmendier, U. and Tate, G. (2015) Behavioral CEOs: The Role of Managerial Overconfidence. The Journal of Economic Perspectives, 29, 37-60. https://doi.org/10.1257/jep.29.4.37

[14] Malmendier, U., Tate, G. and Yan, J. (2011) Overconfidence and Early-Life Experiences: The Effect of Managerial Traits on Corporate Financial Policies. The Journal of Finance, 66, 1687-1733. https://doi.org/10.1111/j.1540-6261.2011.01685.x

[15] Gervais, S., Heaton, J.B. and Odean, T. (2002) The Positive Role of Overconfidence and Optimism in Investment Policy. Mimeo, University of California, Berkeley. 
[16] Lin, Y.-H., Hu, S.-Y. and Chen, M.-S. (2005) Managerial Optimism and Corporate Investment: Some Empirical Evidence from Taiwan. Pacific-Basin Finance Journal, 13, 523-546.

[17] Glaser, M., Schäfers, P. and Weber, M. (2008) Managerial Optimism and Corporate Investment: Is the CEO Alone Responsible for the Relation?

[18] Malmendier, U. and Tate, G. (2005) CEO Overconfidence and Corporate Investment. The Journal of Finance, 60, 2661-2700. https://doi.org/10.1111/j.1540-6261.2005.00813.x

[19] Park, J.H., Kim, C., Chang, Y.K., et al. (2015) CEO Hubris and Firm Performance: Exploring the Moderating Roles of CEO Power and Board Vigilance. Journal of Business Ethics, 1-15. https://doi.org/10.1007/s10551-015-2997-2

[20] Deshm, U. and Goelam, H. (2009) CEO Overconfidence and Dividend Policy: Theory and Evidence. Department of Finance, Depaul University.

[21] Luo, M. (2011) A Bright Side of Financial Constraints in Cash Management. Journal of Corporate Finance, 17, 1430-1444.

[22] Fazzari, S.M., Hubbard, R.G. and Petersen, B.C. (1988) Financing Constraints and Corporate Investment. Brookings Papers on Economic Activity. https://doi.org/10.2307/2534426

[23] Brown, R. and Sarma, N. (2007) CEO Overconfidence, CEO Dominance and Corporate Acquisitions. Journal of Economics and Business, 59, 358-379.

[24] Altman, E.I. (1968) Financial Ratios, Discriminant Analysis and the Prediction of Corporate Bankruptcy. Journal of Finance, 23, 589-609. https://doi.org/10.1111/j.1540-6261.1968.tb00843.x

[25] Zhang, L. and Zeng, W. (2004) The Credit Analysis of Chinese Listed Companies Based on Z Model. Financial Analysis, 30, 5-13.

\section{Submit or recommend next manuscript to SCIRP and we will provide best service for you:}

Accepting pre-submission inquiries through Email, Facebook, LinkedIn, Twitter, etc. A wide selection of journals (inclusive of 9 subjects, more than 200 journals)

Providing 24-hour high-quality service

User-friendly online submission system

Fair and swift peer-review system

Efficient typesetting and proofreading procedure

Display of the result of downloads and visits, as well as the number of cited articles

Maximum dissemination of your research work

Submit your manuscript at: http://papersubmission.scirp.org/

Or contact me@scirp.org 